\title{
As Repúblicas Estudantis da Universidade Federal de Ouro Preto, Brasil
}

Otávio Luis Machado

\section{(2) OpenEdition}

\section{Journals}

Edição electrónica

URL: http://journals.openedition.org/rccs/1174

DOI: $10.4000 /$ rccs. 1174

ISSN: 2182-7435

Editora

Centro de Estudos Sociais da Universidade de Coimbra

\section{Edição impressa}

Data de publição: 1 outubro 2003

Paginação: 197-199

ISSN: 0254-1106

\section{Refêrencia eletrónica}

Otávio Luis Machado, «As Repúblicas Estudantis da Universidade Federal de Ouro Preto, Brasil »,

Revista Crítica de Ciências Sociais [Online], 66 | 2003, posto online no dia 01 outubro 2012, consultado o 15 setembro 2020. URL : http://journals.openedition.org/rccs/1174 


\section{Noticiário}

\section{As Repúblicas Estudantis da Universidade Federal de Ouro Preto, Brasil}

A cidade brasileira de Ouro Preto, localizada na região central de Minas Gerais, é conhecida pelo importante papel que teve na economia brasileira durante o "Ciclo do Ouro", especialmente no século XVIII. Foi também palco da chamada "Inconfidência Mineira", um dos movimentos independentistas da história do Brasil.

Em 20 de março de 1823, Ouro Preto, até então chamada Vila Rica, é elevada a capital da Província de Minas Gerais, estatuto que se manteve até finais do mesmo século. Em 1897, a capital de Minas Gerais passa para Belo Horizonte, que foi planeada e construída exclusivamente para sediar a administração política do Estado devido às limitações geográficas de Ouro Preto. Como consequência, houve um esvaziamento populacional em cerca de $40 \%$ (Meniconi, 2000).

Nesse cenário as repúblicas assumiram papéis importantes na conservação e na divulgação do patrimônio histórico. Quando da transferência da capital para Belo Horizonte, os imóveis disponíveis tornaram-se fartos na cidade. Muitas destas casas foram cedidas ou ocupadas pelos estudantes, que as mantiveram. Quanto às casas cedidas, as famílias a liberavam porque era melhor deixá-los nas mãos dos estudantes que a cuidariam do que deixar desabá-las ou ser ocupadas por estranhos. A cidade recebeu, em 1933, o título de cidade "Monumento Nacional", algo então inédito no país. Desde 12 de Dezembro de 1980, Ouro Preto é considerada cidade Patrimônio Cultural da Humanidade, primeiro título a ser concedido a uma cidade brasileira pela Unesco em reconhecimento de sua importância cultural, e ressaltan- do a necessidade de sua preservação. Torna-se, desta forma, o maior conjunto urbano tombado do Brasil.

\section{A UFOP e as Repúblicas}

As primeiras instituições de ensino superior de Ouro Preto foram a Escola de Farmácia, fundada em 1839, e a Escola de Minas, em 1876. Porém, a Universidade Federal de Ouro Preto (UFOP) só foi criada em 1969, integrando inicialmente apenas aquelas duas escolas. Nos anos seguintes nascem o Instituto de Ciências Humanas e Sociais (ICHS), o Instituto de Ciências Exatas e Biológicas (ICEB), a Escola de Nutrição (ENUT), o Instituto de Filosofia, Artes e Cultura (IFAC), e outros.

A grande maioria dos estudantes da UFOP são originários da própria região, sendo recrutados principalmente nos estados de Minas Gerais, São Paulo e Espírito Santo, vivendo a sua grande maioria nas casas de estudantes, conhecidas por «Repúblicas», (nome adoptado a partir da influência da Universidade de Coimbra). Desta forma, houve, inclusive, intercâmbios entre estudantes de Ouro Preto e Coimbra, como em 1951, quando os estudantes de Coimbra visitaram Ouro Preto e foram recebidos pelos estudantes da Escola de Minas. Os coimbrãos estavam na solenidade usando capas pretas - os seus tradicionais trajes -, enquanto os estudantes de Ouro Preto, na ausência de uma vestimenta tradicional, improvisavam-se com simples lençóis brancos como forma de caracterização no evento (atas estudantis).

Segundo levantamentos recentes da UFOP os tipos de habitações dos estudantes dis- 
tribuem-se do seguinte modo: repúblicas particulares $(39 \%)$; repúblicas federais $(23 \%)$; casa de família $(17,1 \%)$; casa própria $(13,4 \%)$; pensão $(5,3 \%)$; alojamentos $(1,6 \%)$; casa paroquial $(0,5 \%)$, ou seja, $62 \%$ dos estudantes moram em algum tipo de república (NEASPOC/UFOP). As repúblicas de Ouro Preto são em parte propriedade da Universidade e outras pertencentes a particulares. As primeiras são à volta de 66 (as mais antigas), pertencem à UFOP e são administradas pelos próprios estudantes, sem cobrança de aluguel. As segundas são casas alugadas pelos estudantes mediante o pagamento de aluguel e são já em número superior a 200.

\section{Breve História das Repúblicas de Ouro Preto}

Depois da mudança de capital para Belo Horizonte (1897), as características de Ouro Preto como cidade estudantil modificaram-se substancialmente, porém, mantiveram-se aspectos como o clima benigno, a água em abundância, a vida tranquila de uma pequena cidade, com famílias e afectuosas e sobretudo a existência de casas em abundância, possíveis de ser alugadas a muito baixo custo pelos estudantes (Racioppi, 1940: 13).

A partir dos anos 40 do século XX, surgiram entidades de assistência estudantil cuja principal função foi a compra ou construção de casas para estudantes. O resultado da atuação da Casa do Estudante de Ouro Preto e da Casa do Estudante da Escola de Minas foi a compra de grandes casas que abrigaram várias repúblicas, as quais viriam a adquirir nomes como $\mathrm{Ca}$ naan, Sparta, Pureza, Reino de Baco e Formigueiro. Devido às dificuldades de manutenção das "repúblicas" estudantis, principalmente no que tange às reparações, a Casa do Estudante de Ouro Preto, transfere 7 repúblicas para o património da UFOP em 1975.
Com o golpe militar de 1964, em Ouro Preto, como em outras cidades brasileiras, ocorreram inquéritos policiais para aprisionamento dos principais opositores ao regime instalado. $\mathrm{Na}$ cidade foram indiciadas 33 pessoas (entre os quais 14 estudantes e 2 professores), sendo que dos estudantes, a sua grande maioria eram moradores de repúblicas e tiveram suas casas revistadas, além da apreensão de objetos (DOPS, 1964).

Os movimentos estudantis vinham reivindicando mais repúblicas. Um acampamento de protesto na Praça Tiradentes em 1967 sob a liderança do Diretório Acadêmico da Escola de Minas, deu lugar a uma compra sistemática de casas para repúblicas por parte da direção desta Escola (Depoimento de César Maia, 2003). Um dos líderes do acampamento, Maia, que é atualmente prefeito do Rio de Janeiro, falou sobre a experiência republicana: "a República Pureza me ensinou a viver um grupo. E por isso deu uma condição para me dirigir à frente do tempo e me abriu o mundo da política" (idem). Nos anos posteriores houve várias "invasões" bem-sucedidas pelos estudantes dos imóveis da Universidade que eram sub-utilizados. Em 1982 são constituídas 14 repúblicas no campus do Morro do Cruzeiro.

A organização das repúblicas, caracteriza-se por princípios como a autogestão, autonomia e cooperação. Existe, portanto, uma auto-suficiência dos estudantes em relação à universidade; a gestão interna baseia-se na democracia directa; há um estímulo à autonomia e liberdade do indivíduo cujo projecto de vida tende conjugar-se com o grupo, com base na cooperação, solidariedade e apoio mútuo. Diferentemente da "habitación de estudiante", que Bourdieu e Passeron identificaram na França em seus estudos (Bourdieu e Passeron, 1969), as "repúblicas” de Ouro Preto não são lugares im- 
postos pelas condições econômicas e sociais dos estudantes, pois a seleção dos novos moradores pelos estudantes considera a possibilidade de trocas de capitais culturais e sociais.

A importância das repúblicas é, pois, inquestionável em Ouro Preto, já que cumprem uma função importante na cidade e na Universidade. Elas fazem parte da memória colectiva dos estudantes, e estiveram no centro de algumas importantes lutas do passado. O último grande movimento estudantil na UFOP (em 1983) teve como principais objectivos a conquista de novas casas, restaurante universitário e a melhoria das condições de ensino, e teve uma forte participação dos estudantes das repúblicas.

\section{Referências Bibliográficas}

Bourdieu, Pierre; Passeron, Jean-Claude (1969), Los estudiantes y la cultura. Barcelona: Editorial Labor.

Racioppi, Vicente de Andrade (1940), Estudantes do Rio Grande do Sul em Ouro Preto. Belo Horizonte: Typ. Castro.

Meniconi, Rodrigo Otávio (2000), A construção de uma cidade-monumento: o caso de Ouro Preto. Belo Horizonte: UFMG (diss. de Mestrado em Arquitetura e Urbanismo).

Otávio Luiz Machado 